\title{
Family Resources and Flourishing at Work: The Role of Core Self-Evaluations ${ }^{1}$
}

\author{
Larissa Maria David Gabardo-Martins ${ }^{2}$ \\ Universidade Salgado de Oliveira, \\ Rio de Janeiro-RJ, Brazil
}

\author{
Maria Cristina Ferreira \\ Universidade Salgado de Oliveira, \\ Rio de Janeiro-RJ, Brazil
}

\author{
Felipe Valentini \\ Universidade Salgado de Oliveira, \\ Rio de Janeiro-RJ, Brazil
}

\begin{abstract}
According to the Work-Home Resources Model, contextual family resources increase personal resources, which, in turn, improve work outcomes. The present study investigated the direct effects of two contextual family resources (work- family enrichment and perceived social support from family) and one personal resource (core self-evaluations) on a work outcome (flourishing at work). The mediational role of core self-evaluations in these relationships was also investigated. The sample was composed of 519 Brazilian psychologists of both sexes. The Structural Equation Modeling showed that the contextual family resources and the personal resource predicted flourishing at work and that core self-evaluations mediated the relationships between contextual resources and flourishing at work. It was concluded that the acquisition of resources within the family and the positive evaluation of one's own life can promote flourishing at work.
\end{abstract}

Keywords: health, labor, family

\section{Recursos da Família e Florescimento no Trabalho: o Papel das Avaliações Autorreferentes}

\begin{abstract}
Resumo: De acordo com o Modelo de Recursos Trabalho-Casa, os recursos contextuais da família aumentam os recursos pessoais que, por sua vez, aumentam os resultados no trabalho. O presente estudo investigou os efeitos diretos de dois recursos contextuais da família (enriquecimento família-trabalho e suporte social percebido da família) e um recurso pessoal (avaliações autorreferentes) em um resultado do trabalho (florescimento no trabalho), bem como o papel mediador das avaliações autorreferentes nestas relações. A amostra foi composta de 519 psicólogos brasileiros de ambos os sexos. A Modelagem de Equações Estruturais demonstrou que os recursos contextuais da família e o recurso pessoal predisseram o florescimento no trabalho; as avaliações autorreferentes mediaram as relações entre os recursos contextuais e o florescimento no trabalho. Concluiu-se que a aquisição de recursos na família e a avaliação positiva da própria vida contribuem para o florescimento no trabalho.
\end{abstract}

Palavras-chave: saúde, trabalho, família

\section{Recursos Familiares y Florecimiento en el Trabajo: EI Papel de las Evaluaciones Autorreferentes}

\begin{abstract}
Resumen: Según el Modelo de Recursos de la Casa y del Trabajo, los recursos contextuales de la familia mejoran los recursos personales, los quais aumentan los resultados en el trabajo. El presente estudio investigó los efectos directos de recursos contextuales de la familia (apoyo social percibido de familia y enriquecimiento familia-trabajo) y de un recurso personal (evaluaciones autorreferentes) sobre un resultado no trabajo (florecimiento en el trabajo) y el papel mediador de las evaluaciones autorreferentes en estas relaciones. La muestra estaba compuesta por 519 psicólogos brasileños de ambos sexos. Lo Modelo de Ecuación Estructural demostró que los recursos contextuales de la familia y el recurso personal predijeron lo florecimiento en el trabajo; las evaluaciones autorreferentes mediaran las relaciones entre los recursos contextuales y el florecimiento en el trabajo. Se concluyó que la adquisición de recursos de la familia y la evaluación positiva de vida propia aumentan lo florecimiento en el trabajo.
\end{abstract}

Palabras clave: salud, trabajo, familia

Flourishing at work is characterized by the proper performance of the individual in the work environment, i.e., thriving and development achieved at work due to one's work

\footnotetext{
${ }^{1}$ Paper derived from the master thesis by the first author, under the advice of the second author and co-advice of the third author, defended in the Graduate Program in Psychology at the Universidade Salgado de Oliveira.

Support: Coordination for the Improvement of Higher Education Personnel (CAPES) of Ministry of Education.

${ }^{2}$ Correspondence address:

Larissa Maria David Gabardo-Martins. Programa de Pós-Graduação em Psicologia, Universidade Salgado de Oliveira, Rua Marechal Deodoro, $\mathrm{n}^{\circ}$ 211, Bloco C, $2^{\circ}$ andar, Centro. CEP 24030-060. Niterói-RJ, Brazil. E-mail: laragabardo@yahoo.com.br
}

(Mendonça, Caetano, Ferreira, Sousa, \& Silva, 2014). The individual who flourishes at work is therefore the one who is happy (has positive moods and emotions) and engaged (shows job satisfaction and motivation) and that who thrives (exhibits vitality and learning) on work activities (Bono, Davies, \& Rasch, 2011).

Studies on flourishing at work are still scarce. Therefore, only a single study addressing this subject was identified in the literature. It included a sample of 63 Dutch nurses, and it found that flourishing at work is particularly positive in individuals high in personal resources when work pressure is low (Bakker \& Sanz-Vergel, 2013). Therefore, it justifies the 
need for further investigations into flourishing at work using different samples in order to deepen the understanding of the nomological network that encompasses this construct.

The occupational category that includes psychologists was used in the present study because most of the Brazilian studies that have been carried out with this occupational group have focused primarily on the factors responsible for stress and burnout (Sanzovo \& Coelho, 2007). Accordingly, there have been few national studies so far focusing on the analysis of the positive aspects related to the health and well-being of these professionals (Barbosa \& Mendes, 2005; Santos \& Cardoso, 2010). However, considering that this category is fundamental for the society's well-being and psychological and mental health, further research that can contribute to a better understanding of the different factors that influence flourishing of psychologists in their professional practice is of great importance.

According to the Work-Home Resources Model (ten Brummelhuis \& Bakker, 2012), resources generated in the family (contextual family resources) lead to an increase in personal resources, which, in turn, improve work outcomes. The contextual family resources arise from the family social context in which the individual is inserted, such as the social support from family members. Personal resources concern the individual himself or herself, that is, the individual's personal, physical, and psychological characteristics such as optimism and self-efficacy. These authors reported that their results were associated with work attitudes and work behaviors, such as work engagement and job satisfaction (ten Brummelhuis \& Bakker, 2012).

Adopting this model as the main theoretical reference, the contextual family resources used in the present study were work-family enrichment and perceived social support from family. Work-family enrichment refers to the ways experiences gained from the family positively affect work (Greenhaus \& Powell, 2006). In other words, the family can contribute to work by reducing work-related stress improving the quality of life in the workplace (Greenhaus $\&$ Powell, 2006). The perceived social support from family consists of how much the individuals perceive that they are supported by family members (Zimet, Dahlem, Zimet, \& Farley, 1988). This is why this construct also plays an important protective role by reducing the impact of organizational stressors (Carlson \& Perrewé, 1999). With regard to the work results which are also inserted in the work-home resources model, this study was focused on obtained in the present study and those of the work-home resources model, were focused on flourishing at work since it refers to the proper performance of the individual in the work environment (Mendonça et al., 2014).

Several studies have been carried out grounded in the Work-Home Resources model demonstrating the positive influence of work-family enrichment and perceived social support from family on many different work outcomes, such as job satisfaction (Carlson, Kacmar, Zivnuska, Ferguson, \& Whitten, 2011; Tabassum, Jahan, \& Rahman, 2013) and job well-being (Mor Barak \& Levin, 2002). Based on the Work-Home Model, it can be supposed that when the family produces rewarding experiences to the individuals by providing support, contributing to their enrichment, and leading them to experience positive feelings and emotions at home; such experiences are transferred to their work (Greenhaus \& Powell, 2006). Consequently, these individuals will probably flourish at their work, i.e., they may view work as gratifying and fulfilling, which leads them to properly perform in their workplace and to feel happy, engaged, and thriving (Mendonça et al., 2014). Therefore, the following hypotheses were formulated: work-family enrichment and perceived social support from family positively predicts flourishing at work (H1); perceived social support from family positively predicts flourishing at work (H2).

According to the Work-Home Resources Model (ten Brummelhuis \& Bakker, 2012), both contextual family resources and personal resources can lead to positive work outcomes. In the present study, the personal resource used was the core self-evaluations, which is a broad and integrative trait associated with the individuals' evaluation of themselves and how they function in the environment in which they live (Judge \& Hurst, 2007). This construct, according to these authors, is composed of four core traits: self-esteem (degree to which an individual likes himself or herself); generalized self-efficacy (belief in the ability to use cognitive resources and adopt strategies to control life events); emotional stability (level of adjustment to difficult and stressful situations); and locus of control (belief in the ability to control life situations).

In sum, individuals with positive core self-evaluations are those who think positively of themselves and believe that they are capable, valuable, and have control over their own lives (Judge \& Hurst, 2007). These individuals tend to be well adjusted, optimistic, and self-confident, and they believe in their self-efficacy and potential (Judge, Erez, Bono, \& Thoresen, 2003).

According to Bono et al., (2011), core self-evaluations are central to flourishing at work since people with high core self-evaluations are likely to have a more positive view of themselves and others, and they evaluate their work in a more positive way and have better social relationships. Consequently, they tend to naturally flourish at work and take a positive, engaged, and forward-looking approach to work, especially when faced with novel and challenging situations (Bono et al., 2011). Accordingly, different studies have gathered evidence that core self-evaluations positively predict job satisfaction (Chang, Ferris, Johnson, Rosen, \& Tan, 2012; Wu \& Griffin, 2012). Based on these theoretical and empirical assumptions, the following hypothesis was formulated: core self-evaluations positively predict flourishing at work (H3).

In addition to the direct relationships between contextual family resources and work outcomes, the Work-Home Resources Model (ten Brummelhuis \& Bakker, 2012) also refers to the mediational role of personal resources in these relationships. Therefore, it can be said that contextual family resources help individuals to develop personal resources, which, in turn, improve work outcomes (ten Brummelhuis \& Bakker, 2012). Different studies have examined the mediational role of individual variables in the relationships between contextual family resources and work outcomes; 
positive humor has been found to mediate the relationship between work-family enrichment and job satisfaction (Carlson, Hunter, Ferguson, \& Whitten, 2014; Carlson et al., 2011). Other investigations have demonstrated the mediational role of core self-evaluations in the relationship of social support with life satisfaction (Song, Kong, \& Jin, 2013) and work engagement (Yan \& Su, 2013).

Therefore, based on the Work-Home Resources Model, it can be supposed that when the individual has more positive family experiences and perceives the support from family, he/she will probably have a more positive view of himself/ herself (ten Brummelhuis \& Bakker, 2012). A more positive self-evaluation may lead the individual to have more positive attitudes towards his/her work and, consequently, to make it flourish naturally (Bono et al., 2011). Based on these statements, the following hypothesis was formulated: core self-evaluations mediate the relationships of work-family enrichment and perceived social support from family with flourishing at work (H4).

Together, the four hypotheses formulated defined the model to be tested in the present study, whose objective, as previously mentioned, was to investigate the direct effects of two contextual family resources (work-family enrichment and perceived social support from family) and one personal resource (core self-evaluations) on a work outcome (flourishing at work). The mediational role of core selfevaluations in the relationships between the contextual family resources and flourishing at work was also investigated.

\section{Method}

\section{Participants}

A total of 519 psychologists from 24 Brazilian states and the Federal District participated in this study. The inclusion criteria were as follows: psychologists who had an active participation in their respective professional association and who were married and/or had at least one child, according to criteria also used by Carlson, Kacmar, Wayne and Grzywacz (2006). Most of the respondents were female (81.1\%) aged $20-67$ years $(M=33.92, S D=10.29)$; their number of years in the practice of profession ranged from 1-33 years $(M=$ $5.86, S D=6.30$ ). Their professional areas varied, and clinical psychology was the most prominent (39.3\%), followed by the human resources $(11.9 \%)$. Some of them also worked in more than one area, for instance those working in clinical and human resources field (5.6\%), or clinical and social work fields (4.6\%).

\section{Instruments}

Work-family enrichment. It was evaluated using a work-family enrichment subscale, which was derived from the Work-Family Enrichment Scale developed by Carlson et al. (2006) and adapted to Brazilian samples by Brazilian authors [Gabardo-Martins, Ferreira, \& Valentini, 2016)]. This subscale is composed of five items which are evaluated using a five-point Likert scale, ranging from 'strongly disagree' (1) to 'strongly agree' (5). Sample item: My involvement in my family helps me expand my knowledge of new things, and this helps me be a better worker. The internal consistency of the scale is 0.91 .

Perceived social support from family. It was measured using one of the dimensions of the Multidimensional Scale of Perceived Support (MSPSS), developed by Zimet et al. (1988) and adapted to Brazilian samples by Brazilian authors [Gabardo-Martins, Ferreira, \& Valentini, in press]. The dimension perceived social support from family is composed of four items which are evaluated using a seven-point Likert scale ranging from 'very strongly disagree' (1) to 'strongly agree' (7). Sample item: My family really tries to help me. The internal consistency of the scale is 0.93 .

Core self-evaluations. They were evaluated using an adapted version of the Core Self-Evaluations Scale, developed by the Judge et al. (2003); it was adapted to the Brazilian context by Ferreira et al. (2013). This scale is a one-factor instrument consisting of 12 items (six are positively-worded and six are negatively-worded) which are evaluated using a five-point Likert scale, ranging from strongly disagree (1) to strongly agree (5), according to the evaluation that the individual evaluation of him/herself. Sample item: When I try, I generally succeed. The internal consistency of the scale is 0.92 .

Flourishing at work. It was measured using the Flourishing at Work Scale, which was based on the Flourishing Scale developed by Diener et al. (2010) and adapted to the work context by Mendonça et al. (2014). This is a one-factor instrument consisting of eight items which are evaluated using a seven-point Likert scale, ranging from 'completely disagree' (1) to 'completely agree' (7). Sample item: At work, I am engaged and interested in my daily activities. The internal consistency of the scale is 0.91 .

\section{Procedure}

Data collection. Initially, a search of psychologists' email addresses was conducted using the social network Facebook, specifically in Facebook groups of psychologists. Messages were then sent to those professionals. Those who agreed to participate in the study and met the inclusion criteria were asked to sign the Informed Consent Form. Subsequently, they were given a link (specially created for this study) to respond to the research instruments.

Data analysis. It was carried out using structural equation modeling and the Mplus software (version 6.12). Initially, confirmatory factor analysis was conducted for each instrument used to confirm their one-factor structures. Subsequently, item parcels were created to reduce model complexity and increase item variability. Accordingly, the correlated items from the same dimension were aggregated according to their means, and each latent variable was estimated by at least three item parcels. In the next step, confirmatory factor analysis was carried out to evaluate different measurement models, in which all the items parcels were inserted. The major measurement model was estimated with four correlated latent variables. Based on this model, the 
average variance extracted was calculated, which was used to assess discriminant validity between the latent variables (Valentini \& Damásio, 2016).

Mediation analyses were carried out in two steps. In the first one, the direct effects of enrichment and social support from family on flourishing were assessed. In the second step, the indirect effects mediated by the core self-evaluations were assessed. The standard errors for the indirect effects of the variable mediator of the relationships between the independent and the dependent variable were estimated by bootstrap resampling approach with 500 samples. The 95\% confidence interval was used, and the following fit indices were analyzed: chi-square (it tests the probability of the theoretical model to fit to the data; the larger the value of $\chi 2$, the poor the fit to the data); Root Mean Square Error of Approximation (RMSEA values below 0.08 indicate good fit; values up to 0.10 indicate fair fit); and Tucker-Lewis Index and Comparative Fit Index (TLI and CFI > 0.90 are considered acceptable, and values > 0.95 are considered excellent).

\section{Ethical Considerations}

The present study was approved by the Research Ethics Committee da Universidade Salgado de Oliveira (Salgado de Oliveira University), CAAE No. 26202713.80000.5289. It adheres to the ethical precepts of the Brazilian Federal Council of Psychology, according to Resolution 466/12 passed by the Conselho Nacional de Saude (CNS, National Health Council).

\section{Results}

\section{Evaluation of the Assessment Instruments Using Confirmatory Factor Analysis}

The results of the confirmatory factor analyses indicated that the one-dimensional models showed good fit or minimally adequate fit. Work-family enrichment scale: factor loading between 0.72 and $0.83(\mathrm{M}=0.78)$; fit indices: $\chi^{2}(\mathrm{df})=13.73$
(3); $\mathrm{CFI}=0.99$; TLI $=0.98$; and RMSEA $=0.08$ ). Social Support from Family Scale: factor loading between 0.86 and $0.93(\mathrm{M}=0.89)$; fit indices: $\chi^{2}(\mathrm{df})=4.78(1)$; CFI $=1.00$; $\mathrm{TLI}=0.99$; and RMSEA $=0.08$. Core self-evaluations scale: factor loading between 0.60 and $0.83(\mathrm{M}=0.70)$; fit indices: $\chi^{2}(\mathrm{df})=261.34$ (52); CFI $=0.92$; $\mathrm{TLI}=0.90$; and RMSEA $=$ 0.09 . Flourishing at work scale: factor loading between 0.60 and $0.83(\mathrm{M}=0.75)$; fit indices: $\chi^{2}(\mathrm{df})=102.54(19)$; CFI $=$ 0.97 ; $\mathrm{TLI}=0.95$; and $\mathrm{RMSEA}=0.09$.

\section{Measurement Models}

Considering that the scales adequately fitted the onedimensional models (even when all items were used), subsequent analyses were carried out based on the item parcels. Therefore, the following models were tested: M1, a one-factor model explaining all items (i.e. discrimination between the scales $=0$ ); M2, a two-factor model with one general factor structuring all explanatory variables and another factor for the dependent variable (i.e. discrimination between the explanatory variables, including the mediator variable $=0$ ); M3, a three-factor model with one factor for the dependent variable, one factor for the mediator variable, and one factor for the other explanatory variables (i.e. discrimination between the explanatory variables, excluding the mediator variable $=0)$; M4, a four-factor model with one factor for each scale used (Table 1).

The first model, with a single dimension for all item parcels, did not fit the data. In this case, an adequate fit would indicate a lack of discriminant validity between dimensions (which did not occur). In the models two and three, latent structures were tested to identify those that would indicate lack of discriminant validity between the explanatory variables (which would indicate collinearity problems). These models also did not fit to the data. Finally, the model with the four theoretical dimensions (only correlated) showed a good fit to the data. All these results together point to the fact that the latent scores of all four scales, when estimated simultaneously, are slightly different from each other.

Table 1

Fit indices of the measurement models

\begin{tabular}{lcccc}
\hline Models & $\chi^{2}(\mathrm{gl})$ & CFI & TLI & RMSEA \\
\hline M1. One-factor model & $1755.18(76)$ & 0.64 & 0.57 & 0.21 \\
M2. two-factor model & $1796.10(75)$ & 0.63 & 0.55 & 0.21 \\
M3. three-factor model & $569.23(73)$ & 0.89 & 0.87 & 0.11 \\
M4. four-factor model & $293.13(70)$ & 0.96 & 0.95 & 0.08 \\
\hline
\end{tabular}

Notes. $\chi^{2}=$ chi-square; $\mathrm{df}=$ degree of freedom; TLI = Tucker Lewis Index; CFI = Comparative Fix Index; RMSEA = Root Mean Square Error of Approximation. 
Table 2

Measurement models: average variance extracted, correlations, and coefficients of determination between latent variables

\begin{tabular}{llcccc}
\hline \multicolumn{1}{c}{ Latent variables } & AVE & 1 & 2 & 3 & 0.27 \\
\hline 1. Work-family enrichment & 0.65 & - & 0.48 & 0.38 & 0.28 \\
2. Perceived social support from family & 0.79 & $0.69^{*}$ & - & - & 0.31 \\
3. Core self-evaluations & 0.68 & $0.62^{*}$ & $0.53^{*}$ & 0.64 \\
4. Flourishing at work & 0.76 & $0.52^{*}$ & $0.80^{*}$ & - \\
\hline
\end{tabular}

Notes. The relationships between the latent variables (estimated by structural equation modeling) are shown below the main diagonal; the coefficients of determination $\left(R^{2}\right)$ are shown above the main diagonal.

In order to expand the discussion about the structure model, Table 2 shows the average variance extracted (AVE), the correlations, and the coefficients of determination $\left(\mathrm{R}^{2}\right)$ between the latent variables. Although there were significant relationships between the latent variables, the coefficients of determination were lower than the average variance extracted. These results indicate that the variances shared across the item parcels contribute more to the estimates of the factor loading than to the relationships between the latent variables. This can provide further evidence of the discriminant validity of the scale scores.

Table 3

Mediation models: non-standardized effects on flourishing at work.

\begin{tabular}{lcc}
\hline & $\begin{array}{c}\text { Model without the } \\
\text { mediatorvariable }\end{array}$ & $\begin{array}{c}\text { Models with the mediator } \\
\text { variable (core self-evaluations) }\end{array}$ \\
\cline { 2 - 4 } Effect & Direct Effect & Direct Effect Indirect Effect \\
\hline Explanatory variables simultaneously estimated in & & $-0.240^{*}$ \\
the models & $0.309^{*}$ & $0.393^{*}$ \\
WFE - Flourish at work & $0.478^{*}$ & $0.833^{*}$ \\
SSF - Flourish at work & & $0.667^{*}$ \\
Separate analyses by variable explanatory & $0.614^{*}$ & $0.330^{*}$
\end{tabular}

Notes. $* p<0,05 ; \mathrm{ns}=$ non-significant $(p>0.05)$

\section{Mediation Models}

Initially, in the first model, the direct effects of workfamily enrichment and social support from family on flourishing (without the mediating effect of the core selfevaluations) were assessed. The model fitted the data $\left(\chi^{2}(\mathrm{df})\right.$ $=113.04(31), \mathrm{CFI}=0.98, \mathrm{TLI}=0.97$, and $\mathrm{RMSEA}=0.07)$, and the effects were statistically significant (according to Table 3). Moreover, the effects of the control variables 'sex' and 'working time' on the dependent variable 'flourishing' were assessed, but these relationships were not statistically significant $(p>0.05)$. Thus, the control variables were excluded from the subsequent models.

In the subsequent models, the variable 'core selfevaluations' was included as a mediator of the relationships. The mediation model of an independent variable was tested based on the controlled direct effect of the other independent variable. For example, when testing the indirect effect of work-family enrichment on flourishing, mediated by the core self-evaluations, the direct effect of the social support on flourishing was also estimated, but the effect of social support on core self-evaluations (mediator variable) was set to 0 . This procedure ensures that the indirect effects are tested independently. The results presented in the upper part of Table 3 indicated an inversion of the direct effect of enrichment on flourishing, which may indicate a possible suppression effect, possibly caused by the strong relationship between flourishing and core self-evaluations $($ Beta $=0.76)$ and between enrichment and core self-evaluations $($ Beta $=0.64)$.

To solve the inverse direct effect problem, the mediation effects were assessed separately for each explanatory variable. In the lower part of Table 3, it can be seen that the direct effect of enrichment on flourishing becomes insignificant when the indirect effect mediated by the core self-evaluations was estimated (in this case, there was no direct effect of the support on flourishing). Based on this result, in the final model, the direct relationship between enrichment and flourishing was set to 0 , and the direct relationship between social support from family and flourishing was freely estimated. The final model fitted well to the data $\left(\chi^{2}(\mathrm{df})=297.20(71), \mathrm{CFI}=0.96\right.$, $\mathrm{TLI}=0.95$, RMSEA $=0.08)$, and the standardized regression coefficients are presented in Figure 1. 


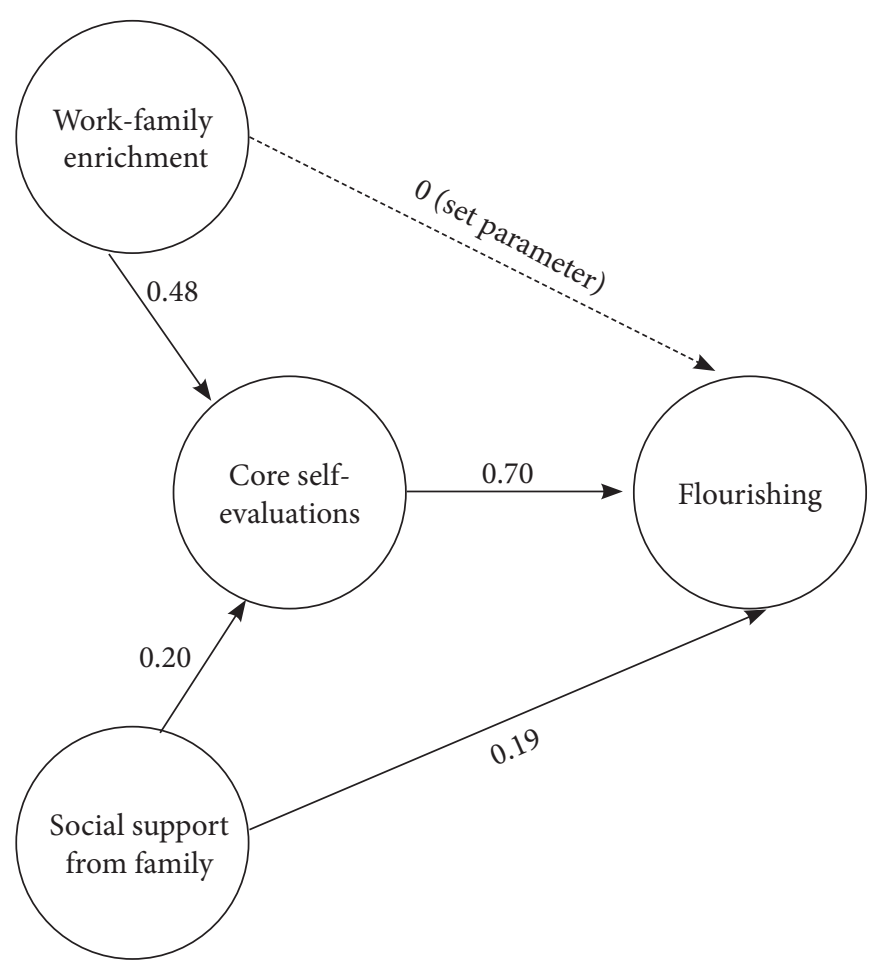

Figure 1. Standardized effects $(\beta)$ of the final mediation model analyzed using structural equation modeling; the factor loadings and item parcels were excluded from the figure.

The final model showed a moderate indirect effect (Beta $=0.33$ ) between work-family enrichment and flourishing and a weak indirect effect $($ Beta $=0.14)$ between social support from family and flourishing. Furthermore, the mediation of core self-evaluations represented $42 \%$ of the total effect between social support and flourishing (including the direct and indirect effects).

\section{Discussion}

The objective of the present study was to investigate the direct effects of two contextual family resources (work-family enrichment and perceived social support from family) and one personal resource (core self-evaluations) on flourishing at work. The mediational role of core self-evaluations in the relationships between contextual resources and flourishing at work was also investigated. The data analyzed using structural equation modeling showed that the contextual family resources positively explained flourishing at work thus confirming Hypotheses 1 and 2.

These results are consistent with those of other studies that have also shown that work-family enrichment positively predicts job satisfaction (Carlson et al., 2011; Tabassum et al., 2013) and that perceived social support from family positively affects job well-being (Mor Barak \& Levin, 2002). According to the model proposed by ten Brummelhuis and Bakker (2012), the resources generated in the family lead to better work outcomes thus improving the quality of life in the workplace. The findings obtained provide empirical support to this theory since it has been found that psychologists who have more rewarding family experiences, that is, who experience more positive feelings and emotions at home, transfer them to their work, making them view their work as gratifying and fulfilling.

It is worthy highlighting that the results obtained also provide empirical support to the Greenhaus and Powell's (2006) beliefs, according to which the family-to-work enrichment brings benefits the receiving domain, i.e., the work domain. However, other authors such as Shockley and Singla (2011) have argued that, especially in the case of affective consequences, the domain in which enrichment originates, which is the family, is the one that benefits the most from this enrichment process. These contradictory views should be further evaluated in empirical investigations.

Hypothesis 3 was also confirmed since the core selfevaluations positively predicted flourishing at work. These findings are consistent with those of other investigations (Chang et al., 2012; Wu \& Griffin, 2012), which also found that core self-evaluations positively predict job satisfaction. These data also support the theory proposed by Bono et al. (2011), according to which people with high core self-evaluations are likely to have a more positive view of themselves and others, and they evaluate their work in a more positive way and have better social relationships, thus demonstrating greater flourishing at work.

It was also found that core self-evaluations partially mediated the relationship between perceived social support from family and flourishing at work, and an indirect effect of work-family enrichment on flourishing was observed through the core self-evaluations. However, it should be noted that such an indirect effect cannot be technically considered a mediation since the direct effect was set to 0 .

Therefore, these results indicate that work-family enrichment and perceived social support from family lead to the improvement in core self-evaluations, which, in turn, contribute to the increase flourishing at work. Thus, Hypothesis 4 was partially confirmed. The findings of the current study are in agreement with those of other studies (Carlson et al., 2011, 2014), in which it was reported that positive mood acted as mediator of the relationship between work-family enrichment and job satisfaction. Our results are also consistent with the findings of Song et al. (2013) and Yan and Su (2013), who found the mediating role of core self-evaluations in the relationships of social support with life satisfaction and work engagement, respectively. Their data and those obtained in this study also give empirical support to the model proposed by ten Brummelhuis and Bakker (2012), according to which contextual family resources help individuals develop personal resources, which, in turn, improve work outcomes.

The results obtained in the present study allow suggestions of strategies that can be implemented in the future to increase the level of flourishing of psychologists' work. Therefore, it is necessary to adopt measures to make these professionals aware of the importance of positive family experiences since these experiences will help them make more positive selfevaluations, i.e., have a more enhanced view of themselves. Moreover, psychologist should understand that such positive self-evaluation is fundamental for their quality of life at work and, consequently, for those to whom they provide care. 
However, the present study also showed some limitations. The first one refers to the fact that the study included a single professional category and most professionals were from a single region in Brazil, the Southeastern region, which makes it difficult to generalize the results to other occupational categories and other Brazilian regions. Another limitation concerns the use of self-report instruments, which were administered at the same time. Therefore, the results obtained may have been influenced by the common method variance, although the anonymity of the research participants was guaranteed as a way to minimize method bias (Podsakoff, MacKenzie, Lee, \& Podsakoff, 2003). A third limitation refers to the cross-sectional design of this study, which makes it impossible to make inferences about causal relations between variables.

With regard to further studies, it is recommended that longitudinal investigations should be carried out addressing the relationships investigated in order to establish the causal relationships between variables. Future research could also focus on the investigation of these relationships in other occupational groups and on the search for other variables that predict flourishing at work (such as family demands) in order to deepen the understanding of the nomological network that encompasses this construct.

\section{References}

Bakker, A. B., \& Sanz-Vergel, A. I. (2013). Weekly work engagement and flourishing: The role of hindrance and challenge job demands. Journal of Vocational Behavior, 83(3), 397-409. doi:10.1016/j.jvb.2013.06.008

Barbosa, C. F., \& Mendes, I. J. M. (2005). Concepção de promoção da saúde de psicólogos no serviço público [Conception of health promotion of psychologists in the public utilities]. Paidéia (Ribeirão Preto), 15(31), 269276. doi:10.1590/S0103-863X2005000200014

Bono, J. E., Davies, S. E., \& Rasch, R. L. (2011). Some traits associated with flourishing at work. In K. S. Cameron \& G. M. Spreitzer (Eds.), The Oxford handbook of positive organizational scholarship (pp. 125-137). New York, NY: Oxford University Press.

Carlson, D. S., Hunter, E. M., Ferguson, M., \& Whitten, D. (2014). Work-family enrichment and satisfaction: Mediating process and relative impact of originating and receiving domains. Journal of Management, 40(3), 845865. doi: $10.1177 / 0149206311414429$

Carlson, D. S., Kacmar, K. M., Wayne, J. H., \& Grzywacz, J. G. (2006). Measuring the positive side of the work-family interface: Development and validation of a work-family enrichment scale. Journal of Vocational Behavior, 68(1), 131-164. doi:10.1016/j.jvb.2005.02.002

Carlson, D. S., Kacmar, K. M., Zivnuska, S., Ferguson M., \& Whitten, D. (2011). Work-family enrichment and job performance: A constructive replication of affective events theory. Journal of Occupational Health Psychology, 16(3), 297-312. doi:10.1037/a0022880
Carlson, D. S., \& Perrewé, P. L. (1999). The role of social support in the stressor-strain relationship: An examination of work-family conflict. Journal of Management, 25(4), 513-540. doi:10.1016/S0149-2063(99)00013-6

Chang, C.-H., Ferris, D. L., Johnson, R. E., Rosen, C. C., \& Tan, J. A. (2012). Core self-evaluations: A review and evaluation of the literature. Journal of Management, 38(1), 81-128. doi:10.1177/0149206311419661

Diener, E., Wirtz, D., Tov, W., Kim-Prieto, C., Choi, D.-W., Oishi, S., \& Biswas-Diener, R. (2010). New well-being measures: Short scales to assess flourishing and positive and negative feelings. Social Indicators Research, 97(2), 143-156. doi:10.1007/s11205-009-9493-y

Ferreira, M. C., Thadeu, S. H., Masagão, V. C., Gottardo, L. F. S., Gabardo, L. M. D., Sousa, S. A. A., \& Mana, T. C. T. (2013). Escala de avaliações autorreferentes: Características psicométricas em amostras brasileiras [The core self-evaluations scale: Psychometric characteristics in Brazilian samples]. Avaliação Psicológica, 12(2), 227232. Retrieved from http://pepsic.bvsalud.org/pdf/avp/ v12n2/v12n2a13.pdf

Greenhaus, J., \& Powell, G. (2006). When work and family are allies: A theory of work-family enrichment. The Academy of Management Review, 31(1), 72-92. Retrieved from http://www.jstor.org/stable/pdf/20159186.pdf

Judge, T. A., Erez, A., Bono, J. E., \& Thoresen, C. J. (2003). The core self-evaluations scale: Development of a measure. Personnel Psychology, 56(2), 303-331. doi:10.1111/j.1744-6570.2003.tb00152.x

Judge, T. A., \& Hurst, C. (2007). Capitalizing on one's advantages: Role of core self-evaluations. Journal of Applied Psychology, 92(5), 1212-1227. doi:10.1037/00219010.92.5.2012

Mendonça, H., Caetano, A., Ferreira, M. C., Sousa, I. F., \& Silva, A. J. (2014). Florescimento e afetos no trabalho [Flourishing and affect at work]. In M. M. M. Siqueira (Ed.), Novas medidas de comportamento organizacional: Ferramentas de diagnóstico e de gestão [New measures of organizational behavior: Diagnostic and management tools] (pp. 172-177). Porto Alegre, RS: Artmed.

Mor Barak, M. E., \& Levin, A. (2002). Outside of the corporate mainstream and excluded from the work community: A study of diversity, job satisfaction and well-being. Community, Work \& Family, 5(2), 133-157. doi:10.1080/13668800220146346

Podsakoff, P. M., MacKenzie, S. M., Lee, J., \& Podsakoff, N. P. (2003). Common method biases in behavioral research: A critical review of the literature and recommended remedies. Journal of Applied Psychology, 88(5), 879-903. doi:10.1037/0021-9010.88.5.879 
Santos, A. F. O., \& Cardoso, C. L. (2010). Profissionais de saúde mental: Estresse, enfrentamento e qualidade de vida [Mental health professionals: Stress, coping and quality of life]. Psicologia: Teoria e Pesquisa, 26(3), 543-548. doi:10.1590/S0102-37722010000300017

Sanzovo, C. E., \& Coelho, M. E. C. (2007). Estressores e estratégias de coping em uma amostra de psicólogos clínicos [Clinical psychologists' stress sources and coping strategies]. Estudos de Psicologia (Campinas), 24(2), 227-238. doi:10.1590/S0103-166X2007000200009

Shockley, K. M., \& Singla, N. (2011). Reconsidering work-family interactions and satisfaction: A metaanalysis. Journal of Management, 37(3), 861886. doi: $10.1177 / 0149206310394864$

Song, G., Kong, F., \& Jin, W. (2013). Mediating effects of core self-evaluations on the relationship between social support and life satisfaction. Social Indicators Research, 114(3), 1161-1169. doi:10.1007/s11205-012-0195-5

Tabassum, A., Jahan, K., \& Rahman, T. (2013). Test of work-to-family and family-to-work models of conflict, enrichment, and satisfaction: An analysis on the female primary school teachers of Bangladesh. World Review of Business Research, 3(3), 47-71. Retrieved from http:// www.wbiconpro.com/432-Ayesha.pdf

ten Brummelhuis, L. L., \& Bakker, A. B. (2012). A resource perspective on the work-home interface: The work-home resources model. American Psychologist, 67(7), 545-556. doi:10.1037/a0027974

Valentini, F., \& Damásio, B. F. D. (2016). Variância média extraída e confiabilidade composta: Indicadores de precisão [Average variance extracted and composite reliability: Reliability coefficients]. Psicologia: Teoria e Pesquisa, 32(2), 1-7. doi:10.1590/0102-3772e322225

Wu, C. H., \& Griffin, M. A. (2012). Longitudinal relationships between core self-evaluations and job satisfaction. Journal of Applied Psychology, 97(2), 331-342. doi:10.1037/ a0025673

Yan, X., \& Su, J. (2013). Core self-evaluations mediators of the influence of social support on job involvement in hospital nurses. Social Indicators Research, 113(1), 299306. doi:10.1007/s11205-012-0093-x

Zimet, G. D., Dahlem, N. W., Zimet, S. G., \& Farley, G. K. (1988). The multidimensional scale of perceived social support. Journal of Personality Assessment, 52(1), 30-41. doi:10.1207/s15327752jpa5201_2
Larissa Maria David Gabardo-Martins is a Ph.D. candidate of the Graduate Program in Psychology at the Universidade Salgado de Oliveira.

Maria Cristina Ferreira is a Professor of the Graduate Program in Psychology at the Universidade Salgado de Oliveira.

Felipe Valentini is a Professor of the Graduate Program in Psychology at the Universidade Salgado de Oliveira.

Received: May. 29, 2015

1st Revision: Nov. 11, 2016

Approved: Jan. 25, 2017

How to cite this article:

Gabardo-Martins, L. M. D., Ferreira, M. C., \& Valentini, F. (2017). Family Resources and Flourishing at Work: The Role of Core Self-Evaluations. Paidéia (Ribeirão Preto), 27(68), 331-338. doi: 10.1590/1982-43272768201711 